\title{
SUBJECT POSITIONS: MONARCHY, CIVIL RELIGION AND FOLK RELIGION IN BRITAIN
}

\author{
Anne RowbotTom \\ Centre for Human Communication, Manchester Metropolitan University \\ 799 Wilmalow Road, Didsbury, Manchester, United Kingdom
}

\begin{abstract}
As Head of State, Head of the Church of England and the living symbol of the national unity, the British monarch embodies the political and religious institutions of the United Kingdom. Consequently, the ceremonies and events involving the monarch and the royal family constitute a central part of the civil religion of the nation-state. One potential problematic of the official discourse on national identity made available through the civil religion is the principle of heredity, which by elevating the status of royal birth simultaneously lowers the status of the mass of the people. However, this positioning does not cause widespread offence, or provoke general hostility towards the institution of monarchy. On the contrary, as the public mourning for Diana Princess of Wales demonstrated, royalty has the power to mobilise the sentiments and actions of millions. Drawing upon fieldwork conducted over the past ten years, my concern in this paper is with unofficial public participation in royal ceremonials and events as folk version of the official civil religion. More particularly I am concerned with the ways in which these folk participants negotiate their socially inferior positioning by switching between the competing discourses of democratic egalitarianism and of heredity status, discourses which the concept of constitutional monarchy seeks to combine.
\end{abstract}

Keywords: religion, state religion, England, national identity, mourning for Diana Princess of Wales, constitutional monarchy

One summer evening in 1990 I stood squashed amongst a mass of people, contained behind crush barriers, outside a cinema in London's West End. This crowd was not waiting to see the film, they were there to see the Duchess of York arrive for a charity performance. When the Duchess stepped from her highly polished, chauffeur driven car, she paused briefly to wave and smile at the crowd and the press photographers, before advancing towards the official reception party lined up to greet her. As she swept past my section of the cheering crowd, resplendent in evening gown and diamond tiara, I overheard an American onlooker complain to his companion, 'Now I really feel like a peasant!' From the tone of self-disgust in his voice it was evident that his use of the term 'peasant' was not being used to denote an identity as a farmer, but carried the connotation of being a person of very low social standing.

Like all public appearances by members of the British royal family this one by the Duchess, was surrounded by ceremonial which, as DoUGLAS (1970) reminds us, serves to highlight social and cultural boundaries. It also dramatises who people are and who others will take them to be (BUCKLEY-KENNEY 1995). For the American this was an event in which the boundaries of social superiority and inferiority be- 


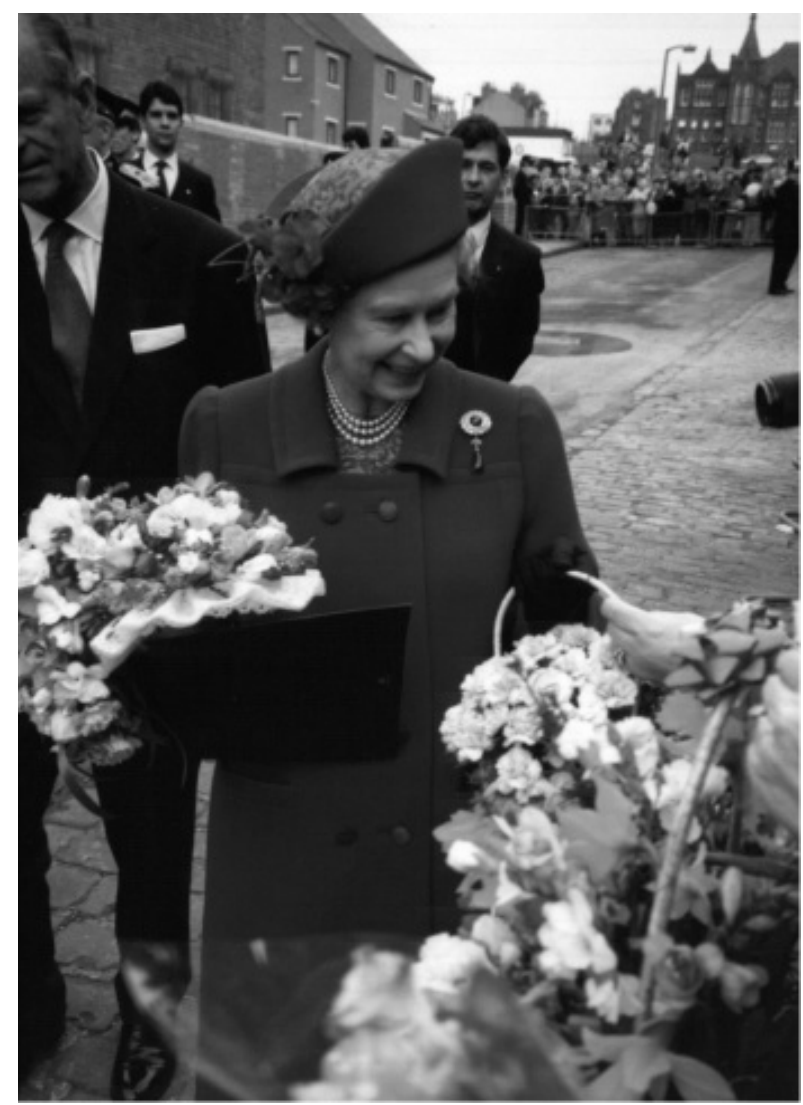

Fig. 1. The Queen receiving flowers from the "real royalists". Photograph Colin Edwards

tween royalty and the crowd were being highlighted and, in the dramatisation of the high status of the Duchess, he read a corresponding statement of his own social inferiority. However, although a similar response was potentially open to everyone else present, the rest of the cheering and excited crowd gave no indication that they shared his interpretation. On the contrary, everyone else appeared to be experiencing the event in a positive, rather than a negative way.

This situation provides, in microcosm, an example of a paradox of British sociopolitical culture. A particularly vivid summary of this is given by Edgar WILSON (1989) who describes the British constitutional monarchy as being:

'incompatible with democracy in principle, yet in practice, amidst widespread and caste based inequality, injustice and real deprivation, the ancient symbol and instrument of hereditary privilege remains unchallenged. It apparently even grows in popularity' (WILSON 1989: 1). 
WILSON's critical stance also demonstrates that negative interpretations of the monarchy are not restricted to Americans, but are also made by Britons (see for example, HITCHENS 1990; WILSON 1989: NAIRN 1988; HAMILTON 1975; BIRNBAUM 1955). However, like that of the American in the crowd, they represent a minority voice in British culture. This situation is not without political significance. Should negative interpretations become the dominant voice, then the continuance of Britain as a constitutional monarchy would be threatened. However, so long as positive interpretations predominate, the constitutional monarchy is likely to remain unchallenged and secure. It is this situation which provides the wider context of my interest in how people construct and maintain a positive interpretation of the relationship between themselves and the monarchy.

\section{THE REAL ROYALISTS}

So far I have been using the term 'people', but in a large scale society, this is too undifferentiated and nebulous a term. My focus of interest is, therefore, a small group of men and women who make a particularly active engagement with the monarchy. I became aware of existence of the 'real royalists', as they style themselves, in the autumn of 1988. During 1989 and 1990 I carried out fieldwork with them, as research for a doctoral thesis in social anthropology (RоwвоттOM 1994) and for an accompanying ethnographic film (HENLEY-ROwBOTTOM 1993). A second period of intensive fieldwork followed in 1996 and 1997 for a television documentary (HENLEY-RowbOTtom 1997) and most recently during the mourning for Diana Princess of Wales (RowвотTOM 1999). In between these periods of extensive fieldwork I have maintained contact with key informants. It is ethnographic data from this ten year involvement with the royalists that informs this paper.

All the royalists I worked closely with collected pictures, books, ceramics, or other memorabilia of the royal family, examples of which were displayed in their homes. Some of these collections are small, but others have grown large enough to fill a whole room in their homes. Many of these objects are commercially produced ceramic commemoratives of coronations, royal weddings, births, anniversaries and other events in the life cycle of the Queen and her family. Other items, such as scrap books, photograph albums and framed individual photographs, they create for themselves. Some of the most highly prized images of the royal family are the photographs the royalists themselves have taken when attending royal visits.

The term 'royal visit' refers to the official visits made by members of the royal family to hundreds of civic, commercial and charitable organisations throughout Britain, during the course of any one year. At the end of each of these visits the royal visitor usually walks over to the crowd and exchanges greetings and brief pleasantries with some of the onlookers. This stage of the proceedings, which has become known as the 'walkabout', is central to the royalists' activities as it provides the chance of a face to face meeting with the royal family. In pursuit of this goal, they regularly undertake long journeys, stand for hours in all weathers, finally drawing 


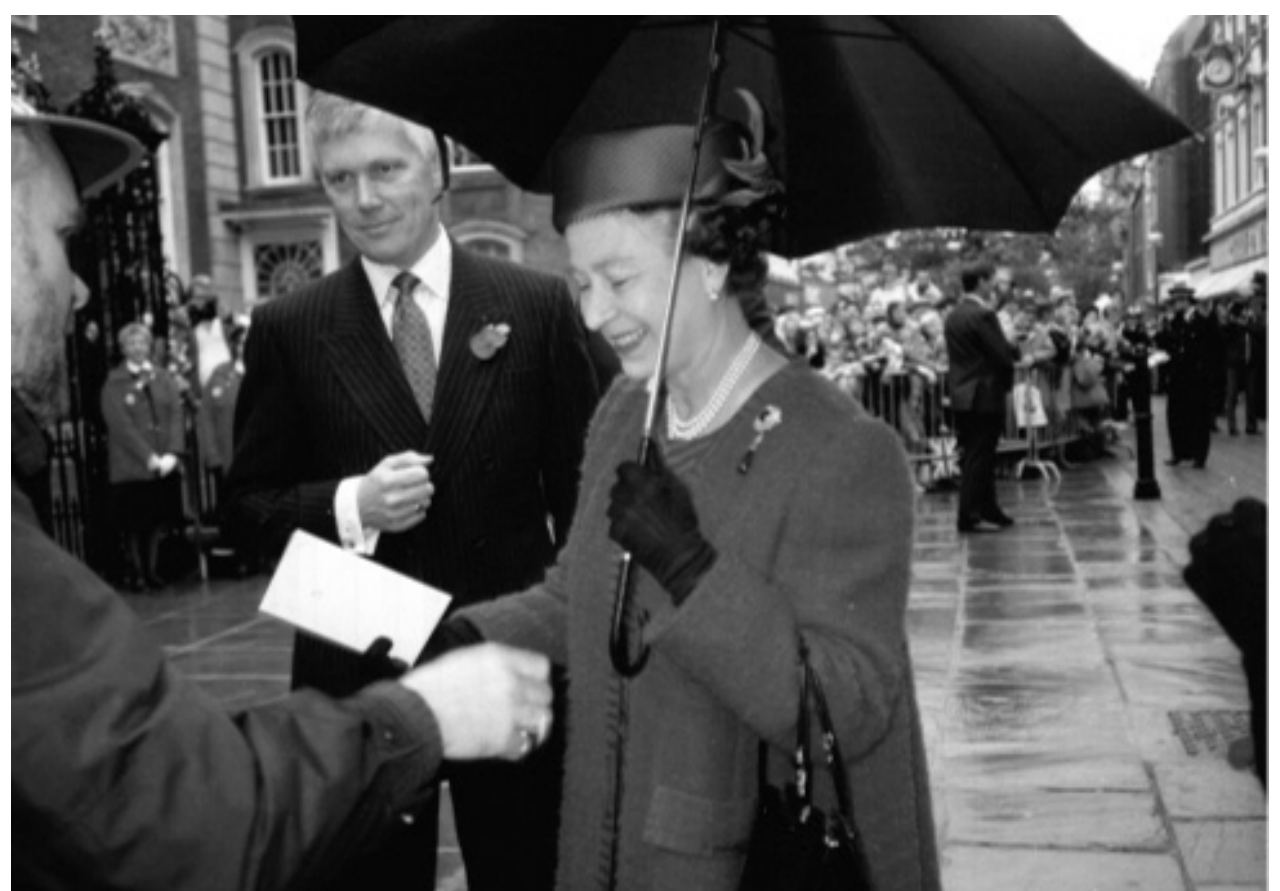

Fig. 2. The Queen receiving a photograph from a "real royalist". Photograph Anne Rowbottom

the royal personage towards them through the offering of a gift. These gifts usually consist of flowers, or a photograph of the intended recipient that the royalist took at a previous meeting. Although the walkabout is part of the official proceedings, the royalists presence and presentations have no official status, they are entirely self motivated. Indeed, it is the willingness to regularly and voluntarily undertake the discomforts of travelling and waiting in the vagaries of the British climate in order to meet with the royal family that constitutes their definition of a 'real royalist'.

The total number of people sharing the royalists' practices is difficult to calculate with any certainty. As they are not part of any formal organisation there is no register of interested people. Consequently, their association with each other is based on the friendship networks that develop out of encounters with like minded people at royal visits. As attendance at these events necessitates travelling to another part of the country, few of the royalists live in the same geographical area. Friendships have to be maintained through letters and telephone calls in which information is exchanged and arrangements made to meet together at future events. Through my key informant's friendship network I met around sixty royalists who regularly travel the country. In addition there were others that I encountered only once, as well as people I never met, but heard about in the royalists' stories, or who featured in media reports. It is, therefore, likely that there are other networks in existence, as well as other individuals who do not wish to join up with others. I also regularly encoun- 
tered people who went to all the royal events which took place in or around their home town or city, but who were not able or willing to travel long distances.

The core of my key informant's friendship network, that is the people with whom he and I most frequently travelled, consisted of fourteen people; nine women and five men. Three of the women were over sixty, one was a teenager, and the remaining five were middle aged. Of the five men, one was a teenager and another was in his late twenties; the other three were middle aged. Both the men and the women were almost exclusively drawn from an upper working, or lower middle class background, without the practices they had developed none would normally expect to have close encounters with royalty.

Although only a small group in relation to the total population of Britain and even as a proportion of the crowds at royal events, the royalists are representative of more widespread sentiments. They often remark that 'many people feel like we do' and this is evident, not only amongst the crowds that turn out for royal visits, but in descriptions of public responses to large scale ceremonials such as, the Coronation (ShiLS-Young 1953); the Investiture of Prince Charles as Prince of Wales (BLUMLER et al 1971); the Queen's Silver Jubilee (ZEIGLER 1977). The most recent large scale expression of public sentiment was the public mourning for Diana Princess of Wales (WALTERS 1999). As I have pointed out elsewhere (RowBOTTOM 1998), the main gifts offered to the Princess in death, such as flowers and her own image, reflected the main items the royalists offered to her in life and, indeed, continue to offer to living members of the royal family.

In discussing the form taken by the public mourning folklorists have readily recognised this as the expression of a folk or vernacular religiosity. This is especially apparent in the construction of shrines (BOWMAN 1999; CHANDLER 1999) at sacred places, and 'an obvious parallel between the journey to Kensington Palace Gates [the home of the Princess] and the purposive journey to some sacred place which is the core of most pilgrimage' (CHANDLER 1999: 150). Following from this my present point is that the folk religiosity, readily recognised in the mourning for Diana, is also to be found in the regular practices of the royalists. They too undertake pilgrimages to sites temporarily made sacred by the presence of royalty to offer flowers and images and, in the display of images and other iconic objects in their homes, they can be said to construct domestic shrines.

Religiosity is also apparent in the experience of transcendency described in the royalists' accounts of how their meetings with royalty put them in contact with their membership of the nation. In the words of one man:

'Unless you have experienced it you can't understand it. Whenever I stand in front of the Queen, or any member of the royal family I am always filled with such feelings of loyalty and pride in being British.'

When, as often happened, he made this, or a very similar statement, other royalists present readily agreed that this was also their experience. In describing the meaning 


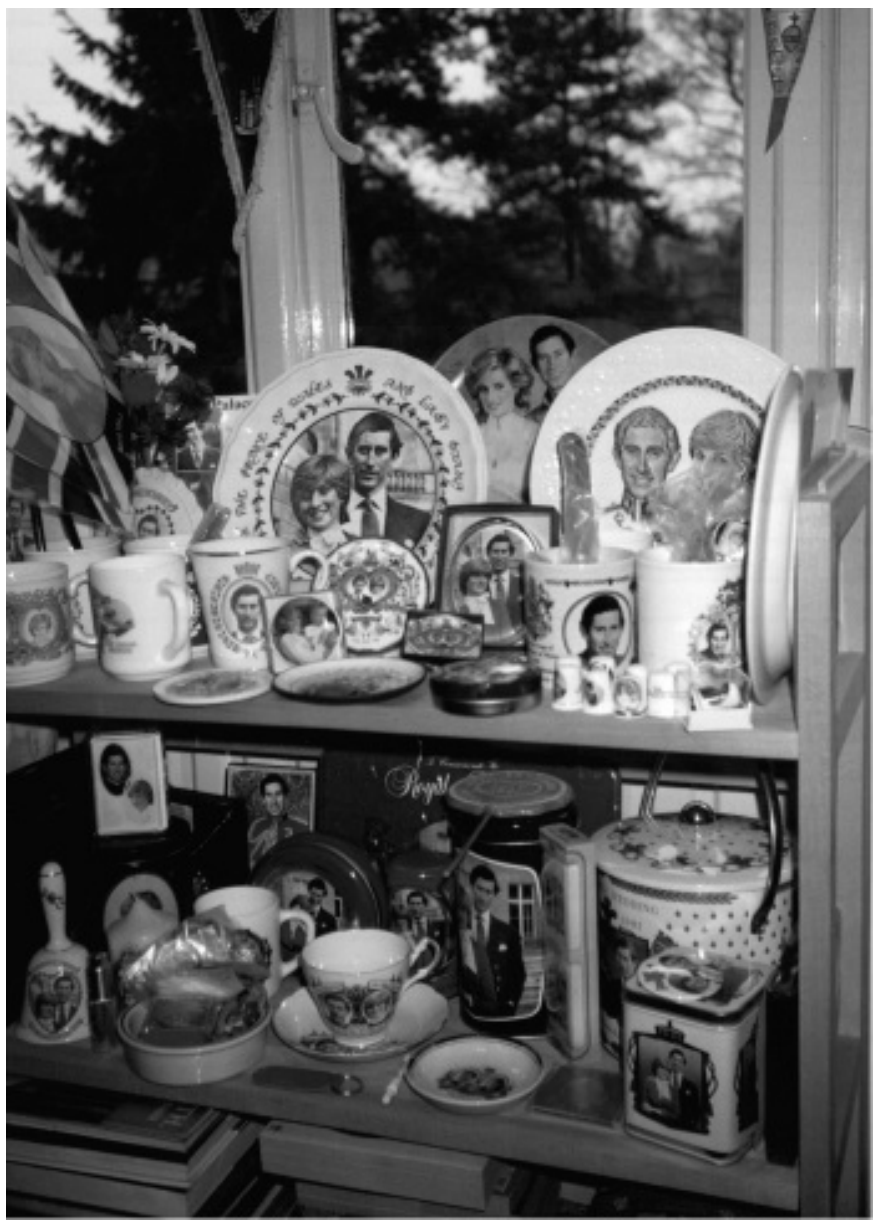

Fig. 3. A domestic "shrine". Photograph Anne Rowbottom

their activities held for them, they invariably made an association with 'Britain', or with 'being British'. The most common kind of statements being, 'The monarchy means Britain', or 'Basically, its about being British'. A strong belief in the royal family as the symbol and guarantee of national identity is evident in a statement made by a female royalist: 'If we lose the royal family what is there? We are just an island with some people on it with nothing to say we are British'.

The equation of the monarchy with the nation is not an idiosyncratic one. Michael BILLIG, in an analysis of conversations about the royal family recorded in sixty three English households, also found expressions of belief in the monarchy as the guarantee of national identity (BILLIG 1992: 33-35). Nor is the equation an insignificant one. What the royalists express as a personal experience echoes the official ideology of the civil religion of the British nation-state. 


\section{CIVIL RELIGION}

Civil religion is a sociological concept which has been defined as 'any set of beliefs and rituals, related to the past, present, and/or future of a people ('nation') which are understood in some transcendental fashion' (HAMMOND 1976: 171). The concept describes practices intended to generate loyalty to a particular nation state (BOCOCK 1985:) in ways which transcend the boundaries of difference within a nation. Transcendence, integration and loyalty are said to be generated through public ceremonies designed to promote national unity and social cohesion (BELLAH 1967). Civil religion is religious, therefore, in the Durkheimian sense of putting people in touch with the transcendent, through an engagement with symbols and ceremonies. It is also religious in the anthropological sense of providing 'a plausible myth of the ordering of existence' (CLARKE-HOOVER 1997:17). The usefulness of the concept lies in its proposal of a religious form through which national unity can be expressed in a heterogeneous and highly differentiated society, as well as in the way 'it proposes a basis for the relationship of the individual to the larger modern society' (MCGUIRE 1992: 184). In Britain, where the sovereign is constitutionally the Head of State, Supreme Governor of the Church of England and the living symbol of national unity (COI 1983: 10; MORRAH 1958: 41), the monarchy retains its traditional role as the constitutional, religious and symbolic centre of the nation. The public appearances of members of the royal family, which are surrounded by ceremonial, form a central component in the official civil religion of the British nation state (BOCOCK 1985; THOMPSON 1986).

The claim that any religion, civil or orthodox, can provide a 'sacred canopy' (BERGER 1967) able to unite and pull together all the complex elements of a modern society has been subject to criticism. Although I accept the view that a totally integrative function is 'not wholly convincing' (TURNER 1991: 58) as the data from my fieldwork demonstrates, the concept cannot be easily dismissed. Therefore, rather than making exaggerated claims for an integrative function I suggest a more productive approach lies in viewing civil religion as a discourse on national unity. As this is put into the public domain through the agencies of the state it constitutes an official discourse in which the monarchy represents the symbol and the guarantee of British identity. It follows from this that, rather than debating whether or not civil religion can have an integrating effect, it is more useful to explore how people interpret and use the discourse.

The political significance of this is indicated by Christopher HITCHENS, when he observes that the monarchy as the guarantee of national identity, 'can only be true for a person who sincerely believes it' (HITCHENS 1990: 34). However, having made this observation HITCHENS then treats 'sincere believers' as unworthy of serious consideration, preferring instead to present an alternative republican discourse. The problem with this kind of approach is that it fails to take account of the importance of 'sincere belief' in the processes that reproduce the 'truth' of the civil religion. It also misses the creativity essential to this process for, as already noted, the discourse of the civil religion is a paradoxical one. Although the Queen may provide 'the living 


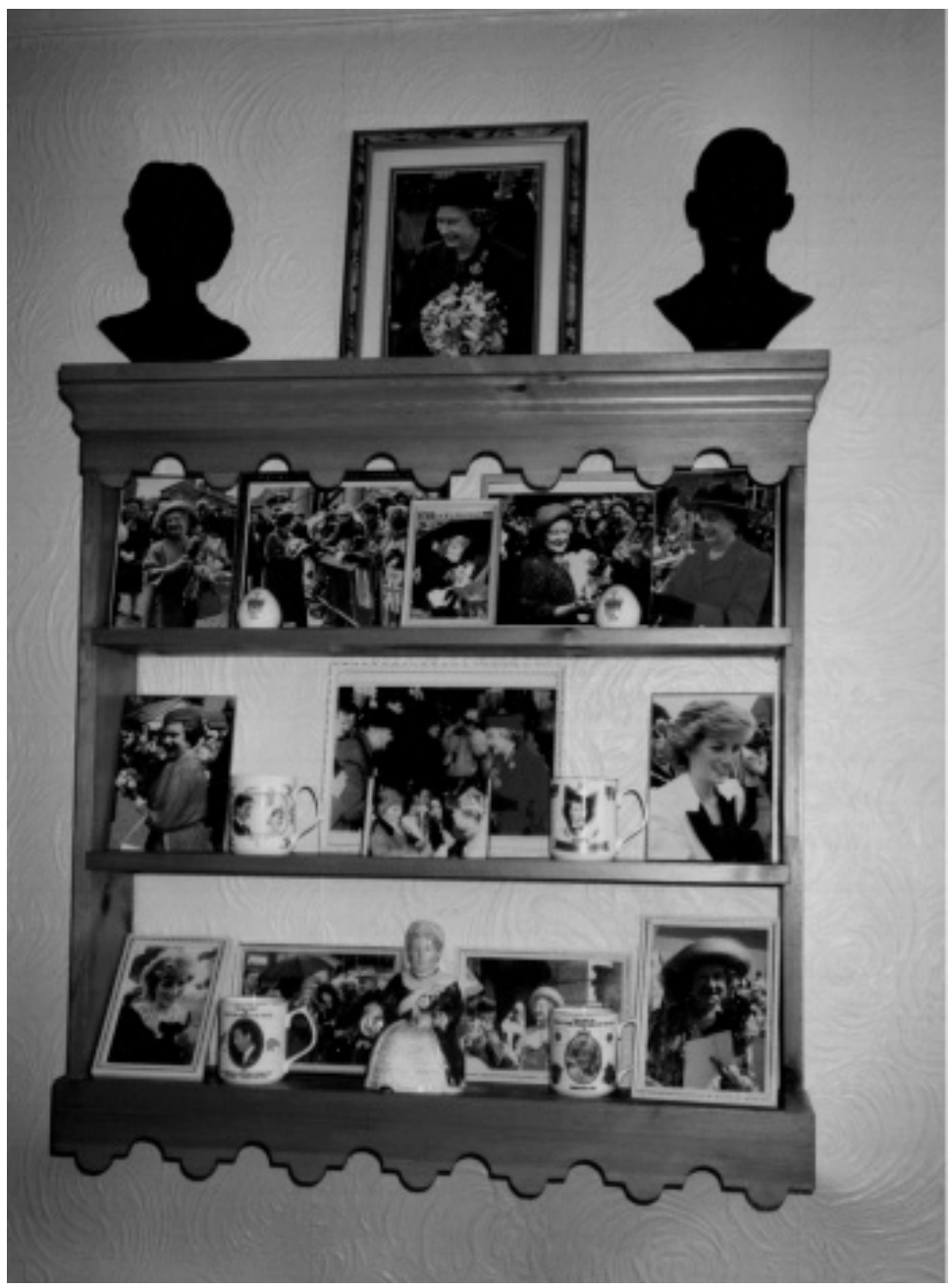

Fig. 4. A domestic "shrine". Photograph Anne Rowbottom

symbol of national unity' (COI 1983:10), her position at the apex of society is premised on hierarchy, making the monarchy a means of categorising people into the social superior and the socially inferior (HAYDEN 1987: 5). The monarchy is, therefore, simultaneously the symbol of unity and difference. This contradiction has to be negotiated by those, such as the royalists, who recognise themselves as being addressed by the discourse of the civil religion and who willingly consent to their 'subjection'. The rest of this paper is concerned with the way the royalists construct a positive view of the monarchy, the nation and themselves. 


\section{FRAMING EVENTS}

Acknowledgement of difference provides the royalists with the knowledge that guides their actions as royalists, setting limitations on what is and what is not possible. Difference provides them with their primary interpretive framework (GOFFMAN 1974). Within this framing it is axiomatic that the royal family represent the nation by virtue of their traditional status at the apex of the social hierarchy. Acknowledgement of difference is evident in the royalists' description of the Queen and the royal family as being worthy of 'respect and admiration' because they are 'very special people'. This contrasts with their descriptions of themselves as 'ordinary people' who are privileged to be able to speak to the royal family.

However, in elaborating on the meaning of their own activities the royalists switch to the frame of unity. As one of the women expressed it: 'by going on royal visits, being interested in royalty and talking about them I believe I am helping to actually keep the monarchy in the country ...' The importance of this, as previously noted, is the royalists' belief that without the monarchy we would have nothing to say that we are British. In this way they rhetorically construct themselves as engaged in a joint enterprise with the royal family to maintain the monarchy and, therefore, British national identity. This sense of partnership is also evident in the way the royalists view their activities. They describe themselves as 'a familiar face in the crowd', with whom the royals can 'hold a friendly conversation', or 'share a laugh and a joke' about previous encounters. In this way the royalists see themselves as lightening the burden of greeting hundreds of strangers who are often 'overawed and tongue tied' in the unfamiliar presence of royalty.

Like all rhetorical framing the royalists understanding of their relationship to the royal family, the monarchy and the nation, is heavily dependent upon the cooperation of others. In securing the cooperation of the royal family the royalists utilise the conventions of gift giving. Offering a gift invokes a cultural obligation to receive (MAUSS 1990, 1950) and acceptance apparently confirms the donor's idea of the recipient and of the relationship that exists between them (SCHWARTZ 1967). Conversely, the rejection of a gift denies the donors' view themselves, the recipient and their relationship. The co-operation of the royal family in accepting gifts is, therefore, essential to the maintenance of the royalists' beliefs. The following incident provides an example of a meaning-threatening situation and of the way one royalist constructed a transformative account of what had taken place.

\section{A TRANSFORMATIVE ACCOUNT}

One very cold afternoon I stood with five royalists around the midpoint of a walkabout by Diana Princess of Wales. Three of the royalists, two middle aged women and one young man, had brought flowers, the other two, a young woman and an older man, had each brought framed photographs of the Princess which they had taken at a previous meeting. The young woman, who for the sake of clarity I shall 


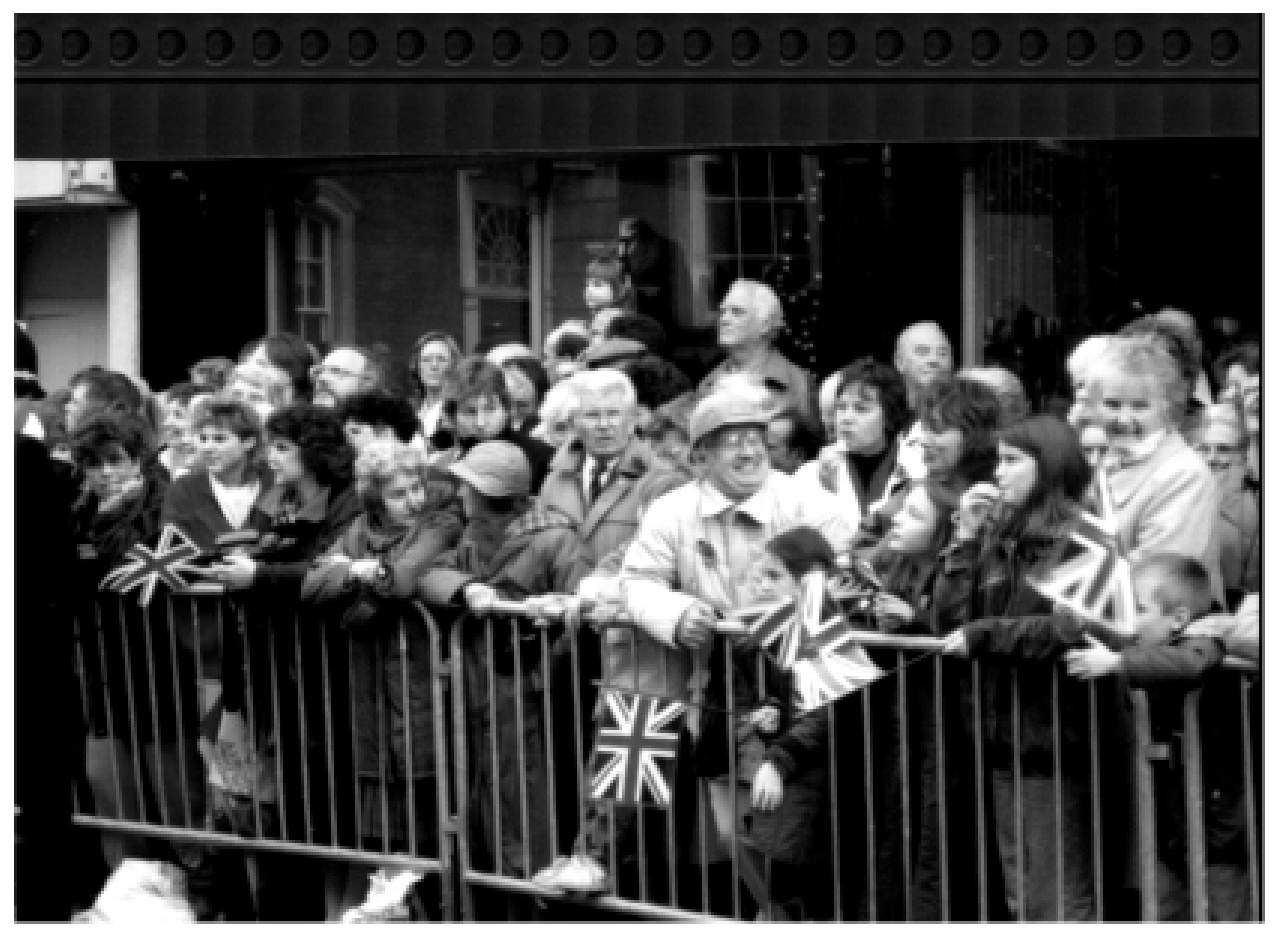

Fig. 5. Part of a crowd gathering to see the Queen. Photograph Anne Rowbottom

refer to as 'Beth', was a little worried that, because her photograph was very slightly out of focus, it might not be of sufficiently good quality to offer to the Princess. The others, after admiring the gilt frame in which the photograph had been placed, assured Beth that the Princess would like it. The walkabout began and proceeded according to everyone's expectations with the Princess shaking hands with as many people as possible and accepting gifts in her usual friendly way. However, when she reached Beth the following exchange took place:

Princess: Is that for me?'

Beth: $\quad$ I'm afraid so.

Princess: Afraid so?, Why don't you ... Will you keep that? I've

Beth: Are you sure?

Princess: Yes. You keep that.

Beth: $\quad$ Is it that bad?

Princess: It isn't that bad, No. I can look in the mirror if I want pictures. You keep that.

Beth: Whatever you say Ma'am.

Princess: You keep that. 
The Princess then moved on, accepting the gifts of others in the same way as before. Because the Princess was always held to be a warm, friendly and caring person, her response to Beth appeared as unusual as it was unexpected. Consequently, the royalists were presented with a meaning-threatening experience that required an explanation which would restore their fundamental assumptions. Immediately after the Princess had left one of the women, who for the sake of clarity I shall refer to as 'Patricia', took me aside and began to develop an explanation of what had taken place.

Patricia began by stating in a puzzled and somewhat shocked tone:

The Princess didn't take Beth's photograph did she? Poor Beth, she must be very upset. I don't understand why it wasn't accepted, do you? Perhaps she didn't take it because it was in a frame and she thought it was too expensive for her to accept from a member of the public.

In explaining the difficulty that might arise over an expensive gift, Patricia stressed the necessity of remembering that, however friendly the Princess might be, she was a member of the royal family. As royalty do not usually accept gifts from ordinary members of the public, it was a privilege to be able to offer them things and, therefore, in order to keep this privilege it was important not to seem presumptuous. Inexpensive items, such as flowers, or unframed photographs were appropriate, but more expensive items were not, as these might seem to presume too close a relationship. Patricia's worry was that if some royalists were perceived as being overly familiar with the royal family, then they might stop accepting gifts from the public altogether. On reflection, however, Patricia realised that as the Princess had accepted a framed photograph from another royalist, her explanation required modification.

Patricia then tried to construct an explanation around Beth's physical appearance, noting that, as Beth was not very tall and of slight build, people regularly thought her to be much younger than her nineteen years. Therefore, she reasoned, it was perfectly possible that the Princess had also assumed Beth to be much younger than her actual age. If so, perhaps the Princess thought that, unlike the adults around her, Beth could not afford to give a photograph in a frame and this was why she asked Beth to keep it. It was also possible, Patricia continued, that if the Princess had thought of Beth as a child, she may have thought she was merely being shown something that a young girl valued and not realised it was being offered as a gift. Perhaps Beth had held it out in too hesitant a manner, suggesting to the Princess that it was being shown, rather than offered to her. In support of this, Patricia reasoned that the Princess could have understood Beth's, 'I'm afraid so', in response to her own question, 'Is that for me?', to mean that the photograph was something with which Beth was reluctant to part, rather than intended as an apology for offering a slightly blurred picture.

That the Princess' refusal had been kindly meant was evident, Patricia thought, 
by her pleasant and friendly manner towards Beth. The photograph may not have been accepted, but there had been nothing nasty in the way it was refused. It was as if the Princess, knowing that Beth valued the picture, had wanted her to keep it for herself. Consequently, Patricia reasoned, Beth should not be embarrassed or distressed by what had taken place. Finally she went on to suggest that the photograph had now acquired something extra special as, in saying to Beth 'you keep that', it was as if the photograph had become a gift from the Princess to Beth herself. Patricia was pleased with this conclusion and she resolved to make this point to Beth later.

\section{DISCUSSION}

In constructing her interpretation Patricia transforms a potentially meaningthreatening encounter into something that restores her understanding of the character of the Princess and her relationship with the royalists. The sociologist, Erving GOFFMAN, describes this as 'remedial work', an activity motivated by the possibility that there has been a deliberate intention to cause offence. That is to say, in constructing her account Patricia understands the possibility of 'interpretations of the act that maximise either its offensiveness to others or its defaming implications for the actor himself [sic]' (GOFFMAN 1971: 138-139). The task that Patricia has undertaken is to prevent a possible or, in GOFFMAN's terminology, a virtual offence becoming an actual one. The problem she faces is that the potential offensiveness of the Princess' action lies in the way it turns the logic of the gift against the royalists. An example of the threat this poses is apparent in an interpretation made by Leslie WOODHEAD, a television producer who saw video footage of the encounter between the Princess and Beth. According to WoODHEAD, the refusal of Beth's photograph was an occasion when the Princess bent under the strain of the royalists' attentions which, at times 'must be more than the royals can bear' (WoODHEAD 1991: 15). This, the worst possible interpretation, threatens the royalists' meaning system by denying the value they attach to their practices. It is this possibility that Patricia's remedial work must avoid confirming.

Motive and intent are significant factors in determining whether an offence has actually taken place, but only the potential, or virtual offender has direct knowledge of these. Usually, clarification can be sought from, or is volunteered by the virtual offender (GOFFMAN 1971). In this case, however, the social difference between the protagonists is such that the royalists cannot ask for a clarification of intent from the Princess herself. Instead it is Patricia who undertakes an explanation that will make safe a disruptive experience. By initially confirming that Beth's gift was the only one to be refused, Patricia established that an offence might have taken place, but effectively located the problem within the parameters of a specific interaction, rather than a response to the whole group. The rest of the explanation could then concentrate on the particular circumstances of this one encounter between the Princess and Beth. 
Patricia's remedial work then began in the interpretive framework of difference. The inequalities of relative social status were highlighted in the suggestion that, by offering an apparently expensive gift, Beth was claiming too close a relationship. In Patricia's account this transgression of the status boundaries not only weakens the obligation to receive (MAUSS 1990, 1950), but also means that the Princess displayed the right relationship to the rules of the social order governing interactions between royalty and commoners. This achieves one aim of remedial work in respect of the Princess, in so far as it minimises the defaming implications for her moral character (GOFFMAN 1971). It is not fully successful, however, as it retains the suggestion that there was a deliberate intent on the part of the Princess to assert her superior status and to remind everyone else of their relative inferiority. In avoiding the danger of confirming this negative possibility, Patricia's developing explanation then switched to the interpretive framework of unity.

In underestimating the age of Beth and seeing her as not much more than a young girl, Patricia constructed the Princess as being just like everyone else. Her behaviour is now to be understood in terms of what anyone would think and do. In this framing unity takes the form of royalty being just 'ourselves writ large' (WILLIAMSON 1986: 76) and their actions can be understood through the knowledge acquired in ordinary, everyday living (BILlig 1992). Patricia's attribution of the actions of the Princess to an understandable and common mistake offers a mitigating claim common to remedial work, namely, that 'the circumstances were such as to make the act radically different from what it appears to have been' (GOFFMAN 1971: 140). That is to say, having wrongly identified Beth as a young girl, the Princess behaves in a protective way, refusing to deprive her of an apparently treasured possession. In this way her actions are radically transformed. Rather than an assertion of social superiority, the action of the Princess becomes one that any responsible and sympathetic adult would adopt towards a young person. In this way Patricia can acknowledge the refusal of the gift as the act of a social superior but, by applying the norms of everyday life, the basis of the superior and inferior relationship is changed. Rather than royal and commoner, the relationship becomes that of adult and child in which the intent of the Princess is not a potentially disturbing assertion of social superiority, but a highly acceptable expression of protectiveness and concern towards a young person.

Finally, in effecting a closure of her account, Patricia returned to the frame of difference and constructed the Princess as an extraordinary person. The magic of monarchy is suggested in the way Beth's picture is said to have gained some special quality through contact with the Princess. In terms of both difference and unity the cooperation of the Princess in confirming the royalists' view of their relationship with the monarchy and, therefore, the nation, has been re-established to Patricia's satisfaction. 


\section{CONCLUDING REMARKS}

Patricia's interpretation is constructed in a very different way from that of the American who provided the starting point for this paper. Like the negative interpretations of constitutional monarchy made by the British republicans (WILSON 1989; HITCHENS 1990; HAMILTON 1975; BIRNBAUM 1955) the response of the American is constructed solely within the interpretive framework of difference. In contrast, Patricia negotiates the possibility of making a negative interpretation of monarchy by switching her explanation from the framework of difference, to that of unity, and then back to difference again. Switching in this way allows her to construct an account in which a potentially demeaning experience can be transformed into a reaffirmation of the relationship between the royalists, the monarchy and the nation.Through the use of difference and unity as alternative and relatively discrete frames of interpretation Patricia is able to negotiate the central paradox of constitutional monarchy and the civil religion. In her remedial work Patricia is following the method widely used by the royalists when explaining the meaning their encounters with royalty hold for them. By using difference and unity as alternative interpretive frames the royalists are able to avoid confronting the contradictions inherent in the central symbol of the civil religion.

This process of negotiation is not without political significance given that the idea of the royal family as the guarantee of national identity is fundamental to the discourse of the civil religion. The importance of understanding the way the larger population of Britain negotiates this official discourse is likely to increase as the British political structure undergoes a substantial change. The present political situation includes a movement not only towards greater European unity, but also to an internal devolving of government to the constituent nations of Great Britain. The outcome of these changes remains uncertain. One possibility is that the break-up of Britain as a unified state has begun, another is that a movement towards a federal state will take place. Whatever the outcome, a crisis of national identity seems likely which promises to be especially acute in England, where 'British' and 'English' are often treated as synonymous. In this developing situation the existing form of civil religion, centring on the monarchy, will also be subject to change. It could provide the official symbol of a pan-British identity, or it could become a focus for the development of a separate English nationalism. Alternatively, of course, the monarchy could fail to provide an adequate symbol of a new national identity and be replaced by something different. In the context of Britain and its constitutional monarchy, the way these changes are working out provides a relevant topic for research. What I have tried to demonstrate in this paper is that in understanding the development of these processes the folk religiosity that surrounds the official discourse of the civil religion provides a relevant topic for further exploration and theorising. 


\section{LITERATURE}

BELLAH, R.

1967: “Civil Religion in America.” Daedalus Vol. 96, 1-21.

BERGER, P.

1967: The Sacred Canopy: Elements of a Sociological Theory of Religion. Garden City, N.Y.: Double Day.

BILLIG M.

1992: Talking of the Royal Family. London-New York: Routledge.

BOWMAN, M.

1999: "A Provincial City Shows Respect: Shopping and Mourning in Bath." In T. WALTER (ed) The Mourning for Diana. Oxford: Berg.

BIRNBAUM, N.

1955: "Monarchs and Sociologists: A Reply to Professor Shils and Michael Young." Sociological Review, (ns) 3, 5-23.

BLUMER, H.

1986 (1969): Symbolic Interactionism. California and London: University of California Press.

Blumler, J. G.-Brown, J. R.-EwBANK, A. J.-Nossiter, T. J.

1971: "Attitudes to the Monarchy: their structure and development during a ceremonial occasion". Political Studies, Vol. 19, 149-171.

BOCOCK, R.

1985: "Religion in Modern Britain.” In R. BOCOCK-K. THOMPSON (eds) Religion and Ideology, Manchester: Manchester University Press.

BuCKLEY, A. D.-KENNEY, M. C.

1995: Negotiating Identity: Rhetoric, Metaphor, and Social Drama in Northern Ireland. Washington and London: Smithsonian Institution Press.

Central Office of Information (COI)

1983: The Monarchy in Britain. London: HMSO. Reference Number 102/RP/83.

CHANDLER, J.

1999: "Pilgrims and Shrines." In T. WALTER (ed) The Mourning for Diana, Oxford: Berg.

Clark, L. S.-HoOver, S. M.

1997: “At the Intersection of Media, Culture, and Religion: A Bibliographic Essay." In Stewart M. Hoover-Knut LundBy (eds) Rethinking Media, Religion, and Culture. Thousand Oaks, London and New Delhi: Sage.

GOFFMAN, E.

1972: Relations in Public. Harmondsworth: Penguin.

1974: Frame Analysis. Harmondsworth: Penguin.

HAMILTON, W.

1975: My Queen and I. London: Quartet.

HAMMOND, P. E.

1976: "The Sociology of American Civil Religion: A bibliographical essay" Sociological Analysis Vol.

HAYDEN, I.

1987: Symbol and Privilege: The Ritual Context of British Royalty. Tucson: University of Arizona Press.

HenLey, P.-RowbotTom, A.

1993: Faces in the Crowd. Granada Centre for Visual Anthropology, University of Manchester.

1997. Royal Watchers. Mosaic Productions for BBC Television, London.

HITCHENS, C.

1990: The Monarchy. London: Chatto and Windus.

MCGUIRE, M. B.

1992: Religion: The Social Context. California: Wadsworth.

MAUSS, M.

1990: The Gift: the form and reason for exchange in archaic societies. Translated by W. D. HALLS.

MORRAH, D.

London: Routledge.

1958: The Work of the Queen. London: William Kimber.

NAIRN, T.

1988: The Enchanted Glass: Britain and its Monarchy. London: Radius and Century Hutchinson. 
Rowbotтom, A.

1994: Royal Symbolism and Social Integration. Unpublished PhD Thesis, University of Manchester.

1998: “The Real Royalists': Folk Performance and Civil Religion at Royal Visits.”, Folklore, Vol. 109, 77-88.

1999: “A Bridge of Flowers." in T. WALTER (ed) The Mourning for Diana. Oxford: Berg.

SCHWARTZ, B.

1967: "The Social Psychology of the Gift." American Journal of Sociology, Vol. 73 (1) 1-11.

SHILS, E.-YOUNG, M.

1953: “The Meaning of the Coronation." Sociological Review, (n.s.), 1, 63-81.

THOMPSON, K.

1986: Beliefs and Ideology. London and New York: Tavistock Publications.

TURNER, B. S.

1991: Religion and Social Theory. London: Sage. (2nd edition)

WILLIAMSON, J.

1987: Consuming Passions. London: Boyer.

WILSON, E.

1989: The Myth of the Monarchy. London: Journeyman Press, and Republic.

WOODHEAD, L.

1991: "What Sacred Bushes, Naked Men, and Royalty Have In Common." European Travel and Life, September, pp. 14-15.

ZEIGLER, P.

1977: Crown and People. London: Collins. 